\title{
Paideusis
}

\section{Women and Education: A Canadian Perspective (Jane Gaskell and Arlene Tigar McLaren (Eds.))}

Debra Shogan

Volume 2, Number 2, 1989

URI: https://id.erudit.org/iderudit/1073417ar

DOI: https://doi.org/10.7202/1073417ar

See table of contents

Publisher(s)

Canadian Philosophy of Education Society

ISSN

0838-4517 (print)

1916-0348 (digital)

Explore this journal

Cite this review

Shogan, D. (1989). Review of [Women and Education: A Canadian Perspective (Jane Gaskell and Arlene Tigar McLaren (Eds.))]. Paideusis, 2(2), 49-52.

https://doi.org/10.7202/1073417ar viewed online.

https://apropos.erudit.org/en/users/policy-on-use/ 


\section{Book Review}

Jane Gaskell and Arlene Tigar McLaren (Editors), Women and Education: A Canadian Perspective (Detselig Enterprises Limited, Calgary, Alberta, 1987). 398 pages.

The sixteen articles in this collection comprise the first booklength overview of women and Canadian education. Most of the papers are from the Women and Education Conference held in Vancouver in 1986. Five were previously published elsewhere. I would have liked to have seen some previously published work by philosophers included since some very important feminist philosophical analysis of educational practice is being done by Canadians. 1

Gaskell and McLaren write that, "the essays in this book are not the result of disinterested academic enterprise; they form part of an action-oriented agenda that can help to eliminate gender-based imbalances in education." Feminist scholars can take much of the credit for insisting that claims to disinterested, value neutral, and objective research are mistaken. They are particularly mistaken in educational research and practice. As Florence Howe has written:

Teaching is a political act in the broadest context of that word: some person is choosing, for whatever reasons, to teach a set of values, ideas, assumptions, and pieces of information, and in doing so, to omit other values, ideas, assumptions, and pieces of information. If all of those choices form a pattern excluding half of the human race, that is a political act one can hardly help noticing .... To include women with seriousness and vision and with some attention to the perspective of women as a hitherto subordinate group is simply another kind of political act. ${ }^{2}$

To the extent that Women and Education reminds us of the legitimacy of this political agenda, it is a long overdue and valuable book.

The articles in Women and Education are organized into four sections: Women as Mothers, Women as Teachers; Unequal Access to Knowledge; The Nature of the Curriculum; Beyond Schooling; Adult Education and Training. Education is defined broadly and, accordingly, encompasses women's educational experiences as educators and educated in situations ranging from day care to adult literacy to job training. The editors introduce each of the four sections with an informative overview of relevant feminist literature and Canadian statistics. 
In their introduction to the book, Gaskell and McLaren describe three phases through which feminist research on women and education has passed. The first phase, a critique of work on sex roles and sex role stereotyping, dismissed the emphasis placed on gender differences because this work has tended to reinforce gender stereotypes. The second phase (one which has not yet been abandoned by some feminist writers, particularly in popular feminist cultural literature) is one in which 'feminine' characteristics are revalued and often valorized. Many feminists now reject this phase since it fails to recognize that 'the feminine' is "partly formed by relation to, and differentiation from a male norm.",3 The third phase consists of a critique of "how our knowledge has been shaped by gender, and more particularly by male domination." Most of the articles in the anthology fit into the latter category, although in my view the force of gender as a principle which organizes the dominant/subordinate relationship of men to women could have been drawn out more thoroughly. Gaskell and McLaren rightly indicate that all feminism insists on understanding the ways in which gender operates in our lives but their reference to 'gender inequality' suggests that they understand gender to be less politically charged than it is understood by others. If, as Genevieve Lloyd writes, "gender is first an inequality, constructed as a socially relevant differentiation, in order to keep that inequality in place,"4 reference to gender inequality is redundant. In her article, "Rethinking 'Femininity': Women in Education," Arlene McLaren could have spent more time considering the implications of the concept 'femininity'. If Lloyd is correct, 'femininity' will never be a satisfactory concept no matter how we attempt to reconstruct it, since entailed in the concept is an unequal relation to 'masculinity'. This is not merely to say that one would have personally preferred the book to have been more philosophical. It is also to say that a clear conception of gender and its implications must inform empirical work.

One of the critiques feminists have made about the assumptions of traditional scholarship is the false universalization of men's experiences as human experiences. It is a more recent realization that reference to 'woman's experience' is also a false universal. Kathy Rockhill's "Literacy as Threat/Desire: Longing to be SOMEBODY" which describes experiences of working-class Latina women as they attempt to upgrade their education and Jane Gaskell's "Course Enrollment in the High School: The Perspective of Working Class Females" make it clear that there are differences among our experiences as women in education. To lose sight of this is to accept another of the harmful implications of gender. Gender not only organizes our lives in such a way that the categories 'woman' and 'man' are constructed as the central way in which we' differentiate ourselves, the 
emphasis on gender difference makes us less able to see differences which occur among women (and among men). Future books on education will need to pursue more thoroughly this implication of gender.

Reviewed by Debra Shogan, University of Alberta 


\section{Notes}

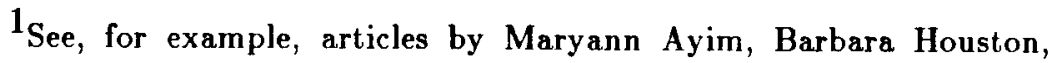
and Kathryn Morgan in Philosophy of Education: Canadian Perspectives. Edited by Donald B. Cochrane and Martin Schiralli. Don Mills, Ontario: Collier Macmillan Canada, Inc. 1982 and articles in Educational Theory, 35, (1985).

2Florence Howe, "Feminist Scholarship: The Extent of the Revolution." In Learning Our Way: Essays in Feminist Education Edited by Charlotte Bunch and Sandra Pollack. Trumansburg, New York: The Crossing Press Feminist Series, 1983, 110.

'3enevieve Lloyd, The Man of Reason: 'Male' and 'Female' in Western Philosophy. Minneapolis: University of Minnesota Press, 1984, 104.

${ }^{4}$ Genevieve Lloyd, "Women as Other: Sex, Gender and Subjectivity," unpublished paper, 1988, 11. 